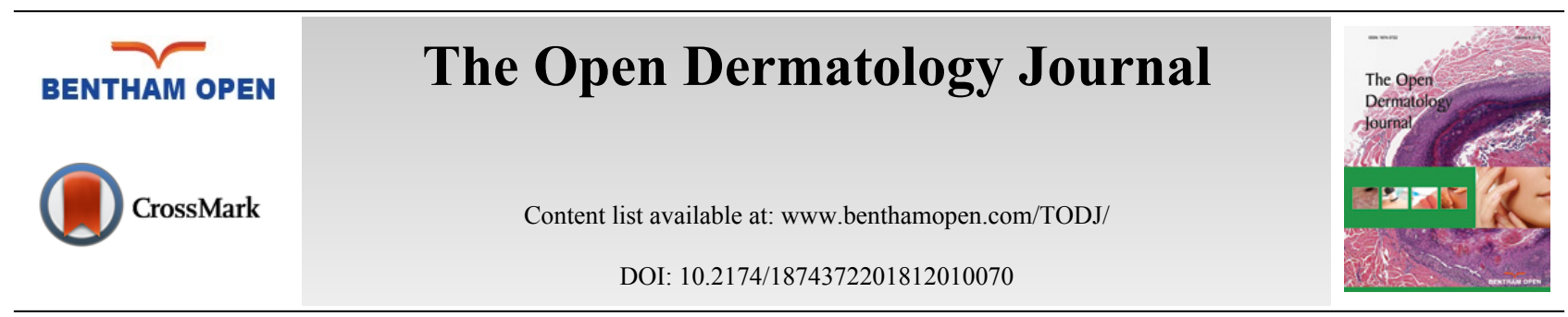

REVIEW ARTICLE

\title{
The Psoriasis Pathogenesis and the Metabolic Risk
}

\author{
Rosalba Buquicchio ${ }^{1}$, Caterina Foti ${ }^{1}$ and Maria Teresa Ventura, ${ }^{2, *}$ \\ ${ }^{I}$ Dermatological Clinic, Department of Biomedical Science and Human Oncology, Medical School, University of Bari \\ "A. Moro", Bari, Italy \\ ${ }^{2}$ Department of Interdisciplinary Medicine, Medical School, University of Bari “A. Moro”, Bari, Italy
}

Received: May 20, 2018

Revised: June 20, 2018

Accepted: July 2, 2018

\begin{abstract}
:
Summary

Psoriasis is a multifactorial disease that can be related to genetic, environmental and immunological causes. Therefore, not only a single factor but different aspects contribute to the onset of the disease, varying from individual to individual. It would be characterized by an abnormal proliferation and differentiation of keratinocytes, mediated by a dysregulation in the auto-immune $\mathrm{T}$ cell response in which several cytokines participate, including Interleukin (IL)-17, IL-17A, IL-12, IL-22, IL-23. These cells and cytokines are responsible for the aggression on skin cells, inflammation and accelerated reproduction of the cells of the epidermis. Due to the chronic inflammation, psoriasis is frequently associated with other concomitant non-dermatological morbid conditions such as arthropathy which can be complicated by a disabling evolution. Psoriasis is also frequently associated with comorbidities such as Cardiovascular Diseases (CVD), hyperlipidemia, diabetes and obesity.

The knowledge of common inflammatory pathways and of the potential links between psoriasis and other diseases should encourage dermatologists to a multidisciplinary approach to psoriasis and to an optimal management also in the light of new therapeutic possibilities.
\end{abstract}

Keywords: Psoriasis, Comorbidities, Cardiovascular disease, IL-17, Metabolic risk, Systemic inflammation.

\section{INTRODUCTION}

Psoriasis is a chronic inflammatory disease of variable severity affecting $2-3 \%$ of the general population and is characterized by an abnormal proliferation and differentiation of keratinocytes, mediated by the dysregulation in the $\mathrm{T}$ cell response [1 - 3].

Psoriasis has long been considered the "disease of the healthy", but many evidences are increasingly contradicting this traditional concept. Today, it is identified as a pathology with systemic involvement and frequent associations with other concomitant non-dermatological morbid conditions [4, 5].

In about $10-30 \%$ of patients it coexists with a form of arthropathy with peripheral or axial articular involvement, responsible for joint pain and functional limitations of the joints, which can be complicated by a disabling evolution [6 $10]$.

These aspects often have an impact on the quality of life, limiting the daily activities [11].

Psoriasis is also frequently associated with other metabolic diseases such as obesity, hyperlipidemia and diabetes. Accumulating data prove that this association predisposes psoriatic patients to an increased cardiovascular risk [12 $15]$.

\footnotetext{
"Address correspondence to this author at the Department of Interdisciplinary Medicine, School of Medicine, University of Bari “A. Moro", Piazza
} G. Cesare, 11, 70124 Bari, Italy; Tel: 0039-080-5478793; E-mail address: mariateresa.ventura@uniba.it. 


\section{PATHOGENESIS}

The etiopathogenesis is immune-mediated and based on a polygenic and multifactorial genetic susceptibility where numerous triggering factors (infections, drugs, stress, trauma, etc.) are involved. The disease has a strong but complex genetic background, so that $60-80 \%$ of white psoriasis are carriers of HLA-Cw6 against $20 \%$ of the population of the same breed [16]. The genetic loci associated with the disease are called psoriasis susceptibility (PSORS). Among the loci associated with psoriasis we find PSORS1 on the short arm of chromosome 6. But it is also possible to mention: PSORS2 on the long arm of chromosome 17, PSORS4 on the long arm of chromosome 1, PSORS5 on the long arm of chromosome 3, PSORS6 on short arm of chromosome 19, PSORS7 on the short arm of chromosome 1, PSORS8 on the long arm of chromosome 16, PSORS9 on the long arm of chromosome 4 and PSORS10 on the short arm of chromosome 18 .

They encode proteins expressed at the level of epidermis, such as corneodesmosina. It is known that in the immunopathogenesis of psoriasis there is a dysregulation of the immune system with an imbalance in favor of the $\mathrm{T}$ helper (Th)1-derived cytokine pattern. Many immunophenotypic studies have shown that the predominant cells in the inflammatory infiltrate of psoriatic skin are polarized towards a Th1 phenotype, are mature T lymphocytes (CD3+) showing signs of activation (CD25+, DR+) and belong to the subclass CD4+ at the level of the dermis and CD8+ in the epidermis.

The first step in the cell-mediated response is characterized by the interaction between the naïve $\mathrm{T}$ cell and the antigen-presenting cell (APC), which determines the activation and differentiation of the T lymphocyte. This initial interaction process involves the $\mathrm{T}$ cell receptor (TCR) and stimulates the interaction between a glycoprotein expressed in the APC called CD40 and its ligand, known as CD40L, expressed in the T lymphocyte. This binding results in a high release of proinflammatory cytokines from mature dendritic cells (DCs), including IL-12 [17].

The presence of mature DC in the dermis is important in the pathogenic psoriatic process for their ability to secrete a vast cytokine network such as Tumor Necrosis Factor (TNF)- $\alpha$, interferon (IFN)- $\alpha$, IL-12, IL-23, and IL-15, always considered indispensable in the formation of the plaque.

In psoriatic plaques myeloid DCs have mainly been found, both mature and immature, able to produce inducible Nitric Oxide Synthase (iNOS) and plasmocytoid DCs. The release of the iNOS in psoriatic patients has allowed us to hypothesize how these cells induce keratinocyte proliferation and vascular endothelial turnover directly [18 - 22].

The imbalance between the two subpopulations of Th1 and Th2, with a consequent deviation towards the pattern of Th1 is mediated by IL-10. This cytokine is able to promote the development of a Th2 pattern cytokine, through the inhibition of the production of INF- $\gamma$ by of T lymphocytes, which is accomplished by blocking the production of IL-12 by the APC. In fact, IL-10 inhibits the release of pro-inflammatory cytokines by blocking directly the activity of the APC, such as monocytes/macrophages and DCs. These observations are confirmed by the studies of Asadullah et al., who emphasized the role of IL-10 in the pathogenesis of psoriasis, showing that the deficit of expression of this cytokine in the skin can play a key role in causing the disease [23].

Recently another subset of Th17 producing IL-17, strongly implicated in the pathogenesis of psoriasis has been identified [24]. The function of Th17 cells in the skin has been studied in the models of psoriasis and it has been observed that these cells are responsible for stimulating proliferative processes, including acanthosis, hyperkeratosis and angiogenesis, for maintaining the inflammatory process, promoting the chemotaxis of monocytes and neutrophils, and further migration and activation of T cells. The cytokinetic profile deriving from Th17 comprises IL-17 A, IL-17 F, IL-20, IL-22, and IL-6. It has been shown that IL-20 and IL-22 induce keratinocyte proliferation in psoriatic skin with amplification of the inflammatory process and lymphocyte activation. The cytokines produced by Th17 also regulate the production of antimicrobial peptides, and this is in favor of the hypothesis that these cells create a connection between the innate and the acquired immunity [17].

The differentiation of naive CD4+ T lymphocytes into Th17 lymphocytes is stimulated by IL-23, which therefore plays a key role in the pathogenesis of psoriasis. A recent study showed that in psoriatic lesions there is an increased expression of IL-23 [25], thus confirming the importance of IL-23 in the pathogenesis of psoriasis, as a part of a complex cellular immune system [24 - 26].

\section{LINKING BETWEEN PSORIASIS AND METABOLIC RISK}

Inflammatory mechanisms that mediate the pathogenesis of the disease overlap between psoriasis and CVD. This 
hypothesis is confirmed by recent studies, in which the role of IL-17A, involved in the activation and proliferation of keratinocytes, is widely emphasized [27, 28].

It has been highlighted that the blockade of IL-17A or its receptor significantly improves clinical, histological and molecular features of psoriasis [29]. In addition, drugs such as secukinumab and ixekizumab, which target selectively IL-17A, are effective in moderate to severe plaque psoriasis [30].

The presence of systemic inflammation in psoriasis has been demonstrated at the whole body level by the fluorodeoxyglucose Positron Emission Tomography-Computed Tomography (PET/CT) [31]. In this case systemic inflammation was detected in focal areas of skin, vessels, joints and visceral tissues of patients with moderate to severe psoriasis [31].

Therefore the role of IL-17 is reaffirmed and overlapping mechanisms appear to support the inflammatory events responsible for the formation of atherosclerotic plaque and of the psoriatic plaque [32].

The hypothesis is further confirmed by the fact that patients with psoriasis have increased the number of Th17 and IL-17 in the circulation and in the psoriatic plaques. Similarly, patients with acute coronary syndrome have increased the number of circulating Th17 and associated cytokines, including IL-17A [33]. Furthermore, IL-17A-induces hyperlipidemia and causes additional human aortic endothelial cell activation [34].

In particular, it has been observed that there is an axis between the two IL: IL-17 and IL-23, where the IL-17 has a proinflammatory and proatherogenic function, and therefore plays a key role in the production of atheroma. Atheroma is also produced in response to the stimulation of IL-23. In particular the IL-23 is in turn responsible for the production of thin fibrous filaments in the lesions, which are a prelude to the plaque instability with consequent easy breaking. Therefore it follows that the IL-23 has an indirect effect in the formation and maintenance of the atherogenic process [35].

Studies on human and animals with ischemic-reperfusion injury of the myocardium, unstable angina, acute myocardial infarction and atrial fibrillation support this pathogenetic model. Plasma IL-17A levels elevated in unstable angina or acute myocardial infarction or atrial fibrillation are directly correlated with the degree of platelet aggregation, suggesting that IL-17A may favor platelet aggregation in patients with acute coronary syndrome. IL-17A promotes vascular remodeling by recruiting neutrophils and triggering apoptosis of cardiomyocytes in animal models [36 - 38]. IL-17A inhibition improves ischemic damage and reduces proaptoptotic marker levels from ischemic injury, suppresses inflammation, decreases the incidence and duration of atrial fibrillation episodes and reduces the probability of development of atrial fibrillation [39]. IL-17A overexpression increases systolic pressure, produces left ventricular hypertrophy and increases mortality [40].

In addition, there are recent studies on a heterodimeric glycoprotein implicated in a great variety of physiological and pathophysiological processes called clusterin that confirm the existence of common pathogenic aspects between psoriasis and the metabolic syndrome [41], confirmimg definitively that a greater predisposition to cardiovascular adverse events, in the course of metabolic syndrome, is mediated by the action of numerous pro-inflammatory cytokines (visfatin, cardiotropin-1), produced by the adipose tissue.

These inflammatory mediators, which play the role of link between obesity, insulin resistance and related inflammatory disorders, are involved in the pathogenesis of psoriasis and represent the possible link between the immune and the metabolic system [42].

\section{PSORIASIS AND METABOLIC IMPLICATIONS}

From a clinical point of view psoriasis is a chronic inflammatory disease that affects not only the skin but is also associated with various comorbidities and an increased risk of developing serious vascular events such as myocardial infarction and stroke. Hypertension, diabetes mellitus, dyslipidemia, obesity and metabolic syndrome (MetS) all contribute to the obvious repercussions on life expectancy in these patients compared to the general population [43].

In particular, various studies have shown that patients with psoriasis have a higher prevalence of MetS compared to the general population [44]. Langan et al. [45] found that psoriasis is associated with MetS with a probability of developing MetS directly proportional to the severity of psoriasis. 


\subsection{Serious Cardiovascular Events}

The risk of major cardiovascular adverse events (including myocardial infarction, stroke and cardiovascular mortality) has been well documented in patients with psoriasis [46]. Epidemiological studies in the United States, Canada and Taiwan [47] have also shown that patients with psoriasis have a higher risk of developing myocardial infarction, especially those with severe psoriasis [48 - 51]. In addition, the life expectancy of patients with severe psoriasis is reduced by approximately 6 years, mainly due to cardiovascular mortality [52].

\subsection{Atherosclerosis}

Atherosclerosis and the subsequent chronic vascular inflammation can be considered among the main factors that can cause myocardial infarction and stroke in these patients. The use of the PET/CT has confirmed the association between the severity of psoriasis and the degree of vascular inflammation [53]. According to some studies there is a link between the Psoriasis Area Severity Index (PASI) and the thickness values of the intimate carotid mean [54].

\subsection{Insulin Resistance and Diabetes Mellitus}

Insulin resistance is a condition that precedes type 2 diabetes mellitus. It appears that inflammation mediators involved in insulin resistance (TNF- $\alpha$, Il-6, leptin, adiponectin) are comparable to those of psoriasis [55 - 57]. Several studies have found an increased risk of diabetes in patients with psoriasis $[58,59]$. Therefore, it appears that the risk of diabetes in psoriasis is linked to insulin resistance [60].

\subsection{Hypertension}

A recent meta-analysis showed an increased prevalence of hypertension among psoriasis patients [61]. It has been recently demonstrated that patients with psoriasis have an alteration of the Renin-Angiotensin-Aldosterone System (RAAS), with high plasma renin activity and elevated enzymatic conversion activity of angiotensin [62, 63].

Adipose tissue is a major source of angiotensinogen, the precursor of angiotensin, which plays an important role in controlling blood pressure. In addition to angiotensinogen, the secretion of resistin and leptin from adipose tissue have also been implicated in hypertension by MetS [64]. All these tests provide also an explanation of the relationship between hypertension and obesity in the case of MetS.

\subsection{Dyslipidemia}

It has been found that patients with psoriasis have dyslipidemia and hypercholesterolemia, with a lowering of the level of High-Density Lipoprotein (HDL) and an increase in the level of Low-Density Lipoprotein (LDL) [65 - 67]. Serum triglyceride levels in patients with psoriasis are also increased if compared to healthy controls [68]. Moreover, it has been shown that in psoriatic patients there are alterations of proteins that bind Fatty Acids (FA) and that, in turn, the metabolism of FA plays a key role in the function of Th17 cells and in the pathogenesis of psoriasis [69]. FA are not only the source of energy and the substrate for forming cell membranes, but also act as signalling molecules in the metabolic pathways involved in the pathogenesis of inflammatory dermatosis such as atopic dermatitis or psoriasis [69]. Myśliwiec et al. have demonstrated the association of circulating FA levels with the metabolic phenotype of psoriatic patients and the positive correlation between the percentage of Polyunsaturated Fatty Acids (PUFA) and PASI in nonobese psoriatic patients [70]. In a study assessing correlations between serum adipocyte Fatty Acid-Binding Proteins (FABP4) and the severity of the disease in psoriatic patients, serum levels of FABP4 were proven to differ from controls [71]. Furthermore, according to Kralisch et al. high levels of FABP4 are closely linked to the development of obesity, insulin resistance, MetS, hypertension, coronary artery disease and atherosclerosis [72]. In a 5-year prospective study it has been stated that FABP4 is an independent predictive marker for the development of MetS [73]. A further link between FABP4 and psoriasis may be a correlation with the TNF- $\alpha$, which is one of the cytokines involved in the pathogenesis of this dermatosis. FABP4 has been linked to angiogenesis and VEGF, that are also highly disturbed in psoriasis [74]

\subsection{Obesity}

Psoriasis is associated with obesity, which is strictly correlated with the severity of the disease [42, 75]. Furthermore, a dose-response relationship between the degree of obesity and the risk of developing psoriasis has also been found [76].

The molecular mechanisms underlying the association between psoriasis and obesity are still being studied. It has 
been reported that the disordered production of adipokine from adipose tissue in obese patients with psoriasis can activate macrophages and stimulate adipocytes to secrete adipocytokine, such as TNF-a, IL-6, leptin and visfatin [77 79]. The circulating levels of leptin are correlated with fat mass; leptin exerts important roles in the inflammation and stimulates the proliferation of keratinocytes and angiogenesis [80]. Adiponectin has anti-inflammatory and antiatherogenic properties and patients with psoriasis have decreased levels of adiponectin [81]. In contrast, Vascular Endothelial Growth Factor (VEGF) which promotes angiogenesis and activation of endothelial cells is increased in psoriatic skin and is correlated with the disease severity [82]. Baran et al. have shown that the measurement of adipokines can be useful to assess the severity of psoriasis and its relationship to other comorbidities. In fact, there would be a significant correlation between BMI and adiponectin levels [83]. In particular, the authors found that serum adiponectin levels increase with the severity of psoriasis defined as the PASI score, while the mean concentration of serum leptin in patients with psoriasis was significantly lower than in the controls [83]. In the light of these results, it is clear that the measurement of leptin in serum could be useful to evaluate the relationship between leptin, obesity and psoriasis.

\section{CONCLUSION}

The new acquisitions that highlight the importance of multiple inflammatory factors in the determination of dysmetabolism and the increased atherosclerotic risk in patients with psoriasis would find full comfort in the light of our data. In fact, patients with psoriasis have a high incidence of CVD, often correlated with the presence of known risk factors including hypertension, obesity, diabetes and hyperlipemia. In light of these data, it would be advisable to sensitize dermatologists for a multidisciplinary screening of psoriasis.

Furthermore, the awareness of the immune-mediated pathogenetic mechanisms and of the potential links between psoriasis and CVD can suggest the efficacy of new suitable therapies to modify or block the evolution of dermatological lesions and correlated comorbidities.

\section{LIST OF ABBREVIATIONS}

\begin{tabular}{|c|c|c|}
\hline FABP4 & $=$ & Adipocyte Fatty Acid-Binding Protein \\
\hline APC & $=$ & Antigen-Presenting Cell \\
\hline CVD & $=$ & Cardio Vascular Disease \\
\hline DCs & $=$ & Dendritic Cells \\
\hline FA & $=$ & Fatty Acid \\
\hline iNOS & $=$ & inducible Nitric Oxide Synthase \\
\hline HDL & $=$ & High Density Lipoproteins \\
\hline IFN & $=$ & Interferon \\
\hline IL & $=$ & Interleukin \\
\hline LDL & $=$ & Low Density Lipoproteins \\
\hline MetS & $=$ & Metabolic Syndrome \\
\hline PUFA & $=$ & Polyunsaturated Fatty Acids \\
\hline PET/ CT & $=$ & Positron Emission Tomography-Computed Tomography \\
\hline PASI & $=$ & Psoriasis Area Severity Index \\
\hline PSORS & $=$ & Psoriasis Susceptibility \\
\hline RAAS & $=$ & Renin-Angiotensin-Aldosterone System \\
\hline TCR & $=$ & $\mathrm{T}$ cell receptor \\
\hline Th & $=$ & T helper \\
\hline TNF & $=$ & Tumor Necrosis Factor \\
\hline VEGF & $=$ & Vascular Endothelial Growth Factor \\
\hline
\end{tabular}




\section{CONSENT FOR PUBLICATION}

Not applicable.

\section{CONFLICT OF INTEREST}

The authors declare no conflict of interest, financial or otherwise.

\section{ACKNOWLEDGEMENTS}

Declared none.

\section{REFERENCES}

[1] Boehncke WH, Schon MP. Psoriasis. Lancet 2015; 386(9997): 983-94.

[2] Lowes MA, Suárez-Fariñas M, Krueger JG. Immunology of psoriasis. Annu Rev Immunol 2014; 32: $227-55$. [http://dx.doi.org/10.1146/annurev-immunol-032713-120225] [PMID: 24655295]

[3] Jabbari A, Johnson-Huang LM, Krueger JG. Role of the immune system and immunological circuits in psoriasis. G Ital Dermatol Venereol $2011 ; 146(1): 17-30$. [PMID: 21317854]

[4] Davidovici BB, Sattar N, Prinz J, et al. Psoriasis and systemic inflammatory diseases: Potential mechanistic links between skin disease and co-morbid conditions. J Invest Dermatol 2010; 130(7): 1785-96. [http://dx.doi.org/10.1038/jid.2010.103] [PMID: 20445552]

[5] Farley E, Menter A. Psoriasis: Comorbidities and associations. G Ital Dermatol Venereol 2011; 146(1): 9-15. [PMID: 21317853]

[6] Chang CA, Gottlieb AB, Lizzul PF. Management of psoriatic arthritis from the view of the dermatologist. Nat Rev Rheumatol 2011; 7(10): 588-98. [http://dx.doi.org/10.1038/nrrheum.2011.125] [PMID: 21912431]

[7] Gladman DD, Antoni C, Mease P, Clegg DO, Nash P. Psoriatic arthritis: Epidemiology, clinical features, course, and outcome. Ann Rheum Dis 2005; 64(Suppl. 2): 14-7. [PMID: 15708927]

[8] Gottlieb A, Korman NJ, Gordon KB, et al. Guidelines of care for the management of psoriasis and psoriatic arthritis: Section 2. Psoriatic arthritis: Overview and guidelines of care for treatment with an emphasis on the biologics. J Am Acad Dermatol 2008; 58(5): 851-64. [http://dx.doi.org/10.1016/j.jaad.2008.02.040] [PMID: 18423261]

[9] Mease PJ. Psoriatic arthritis: Update on pathophysiology, assessment and management. Ann Rheum Dis 2011; 70 (Suppl. 1): 77-84. [http://dx.doi.org/10.1136/ard.2010.140582] [PMID: 21339225]

[10] Ciocon DH, Kimball AB. Psoriasis and psoriatic arthritis: Separate or one and the same? Br J Dermatol 2007; 157(5): 850-60. [http://dx.doi.org/10.1111/j.1365-2133.2007.08148.x] [PMID: 17725671]

[11] Rapp SR, Feldman SR, Exum ML, Fleischer AB Jr, Reboussin DM. Psoriasis causes as much disability as other major medical diseases. J Am Acad Dermatol 1999; 41(3 Pt 1): 401-7.

[http://dx.doi.org/10.1016/S0190-9622(99)70112-X] [PMID: 10459113]

[12] Vena GA, Vestita M, Cassano N. Psoriasis and cardiovascular disease. Dermatol Ther 2010; 23(2): $144-51$. [http://dx.doi.org/10.1111/j.1529-8019.2010.01308.x] [PMID: 20415821]

[13] Armstrong AW, Harskamp CT, Armstrong EJ. Psoriasis and the risk of diabetes mellitus: A systematic review and meta-analysis. JAMA Dermatol 2013; 149(1): 84-91. [http://dx.doi.org/10.1001/2013.jamadermatol.406] [PMID: 23407990]

[14] Augustin M, Reich K, Glaeske G, Schaefer I, Radtke M. Co-morbidity and age-related prevalence of psoriasis: Analysis of health insurance data in Germany. Acta Derm Venereol 2010; 90(2): 147-51. [http://dx.doi.org/10.2340/00015555-0770] [PMID: 20169297]

[15] Mallbris L, Akre O, Granath F, et al. Increased risk for cardiovascular mortality in psoriasis inpatients but not in outpatients. Eur J Epidemiol 2004; 19(3): 225-30.

[http://dx.doi.org/10.1023/B:EJEP.0000020447.59150.f9] [PMID: 15117115]

[16] Gudjonsson JE. Genetic variation and psoriasis. G Ital Dermatol Venereol 2008; 143(5): 299-305. [PMID: 18833071]

[17] O’Neill JL, Kalb RE. Ustekinumab in the therapy of chronic plaque psoriasis. Biologics 2009; 3: 159-68. 
[PMID: 19707405]

[18] Serbina NV, Salazar-Mather TP, Biron CA, Kuziel WA, Pamer EG. TNF/iNOS-producing dendritic cells mediate innate immune defense against bacterial infection. Immunity 2003; 19(1): 59-70. [http://dx.doi.org/10.1016/S1074-7613(03)00171-7] [PMID: 12871639]

[19] Wollenberg A, Wen S, Bieber T. Phenotyping of epidermal dendritic cells: Clinical applications of a flow cytometric micromethod. Cytometry 1999; 37(2): 147-55. [http://dx.doi.org/10.1002/(SICI)1097-0320(19991001)37:2<147::AID-CYTO8>3.0.CO;2-Y] [PMID: 10486527]

[20] Nestle FO, Turka LA, Nickoloff BJ. Characterization of dermal dendritic cells in psoriasis. Autostimulation of T lymphocytes and induction of Th1 type cytokines. J Clin Invest 1994; 94(1): 202-9. [http://dx.doi.org/10.1172/JCI117308] [PMID: 8040262]

[21] Uyemura K, Yamamura M, Fivenson DF, Modlin RL, Nickoloff BJ. The cytokine network in lesional and lesion-free psoriatic skin is characterized by a T-helper type 1 cell-mediated response. J Invest Dermatol 1993; 101(5): 701-5. [http://dx.doi.org/10.1111/1523-1747.ep12371679] [PMID: 7693825]

[22] Lew W, Bowcock AM, Krueger JG. Psoriasis vulgaris: Cutaneous lymphoid tissue supports T-cell activation and "Type 1" inflammatory gene expression. Trends Immunol 2004; 25(6): 295-305. [http://dx.doi.org/10.1016/j.it.2004.03.006] [PMID: 15145319]

[23] Asadullah K, Sterry W, Volk HD. Interleukin-10 therapy: Review of a new approach. Pharmacol Rev 2003; 55(2): 241-69. [http://dx.doi.org/10.1124/pr.55.2.4] [PMID: 12773629]

[24] Johansen C, Usher PA, Kjellerup RB, Lundsgaard D, Iversen L, Kragballe K. Characterization of the interleukin-17 isoforms and receptors in lesional psoriatic skin. Br J Dermatol 2009; 160(2): 319-24. [http://dx.doi.org/10.1111/j.1365-2133.2008.08902.x] [PMID: 19016708]

[25] Krueger GG, Langley RG, Leonardi C, et al. A human interleukin-12/23 monoclonal antibody for the treatment of psoriasis. N Engl J Med 2007; 356(6): 580-92

[http://dx.doi.org/10.1056/NEJMoa062382] [PMID: 17287478]

[26] Yawalkar N, Tscharner GG, Hunger RE, Hassan AS. Increased expression of IL-12p70 and IL-23 by multiple dendritic cell and macrophage subsets in plaque psoriasis. J Dermatol Sci 2009; 54(2): 99-105. [http://dx.doi.org/10.1016/j.jdermsci.2009.01.003] [PMID: 19264456]

[27] Nestle FO, Kaplan DH, Barker J. Psoriasis. N Engl J Med 2009; 361(5): 496-509. [http://dx.doi.org/10.1056/NEJMra0804595] [PMID: 19641206]

[28] Golden JB, McCormick TS, Ward NL. IL-17 in psoriasis: Implications for therapy and cardiovascular co-morbidities. Cytokine 2013; 62(2): 195-201. [http://dx.doi.org/10.1016/j.cyto.2013.03.013] [PMID: 23562549]

[29] Krueger JG, Fretzin S, Suárez-Fariñas M, et al. IL-17A is essential for cell activation and inflammatory gene circuits in subjects with psoriasis. J Allergy Clin Immunol 2012; 130(59): 145-54.

[30] Thaci D, Humeniuk J, Frambach Y, et al. Secukinumab in psoriasis: Randomized, controlled phase 3 trial results assessing the potential to improve treatment response in partial responders (STATURE). Br J Dermatol 2015; 173(64): 777-87.

[31] Mehta NN, Yu Y, Saboury B, et al. Systemic and vascular inflammation in patients with moderate to severe psoriasis as measured by [18F]fluorodeoxyglucose positron emission tomography-computed tomography (FDG-PET/CT): A pilot study. Arch Dermatol 2011; 147(67): 1031-1039.

[32] Armstrong AW, Voyles SV, Armstrong EJ, et al. A tale of two plaques: Convergent mechanisms of T-cell-mediated inflammation in psoriasis and atherosclerosis. Exp Dermatol 2011; 20(20): 544-49 .

[33] Cheng X, Yu X, Ding YJ, et al. The Th17/Treg imbalance in patients with acute coronary syndrome. Clin Immunol 2008; 127(69): 89-97 .

[34] Mai J, Nanayakkara G, Lopez-Pastrana J, et al. Interleukin-17A promotes aortic endothelial cell activation via transcriptionally and posttranslationally activating p38 mitogen-activated protein kinase (MAPK) pathway. J Biol Chem . 2016; 291(71): 4939-54 .

[35] Chen S, Crother TR, Arditi M. Emerging role of IL-17 in atherosclerosis J Innate Immun 2010; 2(35): 325-33.

[36] Zhang S, Yuan J, Yu M, et al. IL-17A facilitates platelet function through the ERK2 signaling pathway in patients with acute coronary syndrome. PLoS One 2012; 7(7): e40641.

[http://dx.doi.org/10.1371/journal.pone.0040641] [PMID: 22808218]

[37] Liao YH, Xia N, Zhou SF, et al. Interleukin-17A contributes to myocardial ischemia/reperfusion injury by regulating cardiomyocyte apoptosis and neutrophil infiltration. J Am Coll Cardiol 2012; 59(73): 420-9

[38] Barry SP, Ounzain S, McCormick J, et al. Enhanced IL-17 signalling following myocardial ischaemia/reperfusion injury. Int J Cardiol 2013; 163(74): 326-4 .

[39] Fu XX, Zhao N, Dong Q, et al. Interleukin-17A contributes to the development of post-operative atrial fibrillation by regulating inflammation and fibrosis in rats with sterile pericarditis. Int J Mol Med 2015; 36(77): 83-92

[http://dx.doi.org/10.3892/ijmm.2015.2204] 
[40] Karbach S, Croxford AL, Oelze M, et al. Interleukin 17 drives vascular inflammation, endothelial dysfunction, and arterial hypertension in psoriasis-like skin disease. Arterioscler Thromb Vasc Biol 2014; 34(80): 2658-68 . [http://dx.doi.org/10.1161/ATVBAHA.114.304108]

[41] Buquicchio R, Foti C, Loconsole F, et al. Clusterin serum level: How does it affect psoriatic patients? J Biol Regul Homeost Agent 2017; 31(33 del mio): 785-9.

[42] Setty AR, Curhan G, Choi HK. Obesity, waist circumference, weight change, and the risk of psoriasis in women. Nurses' health study II. Arch Intern Med 2007; 167(34 del mio): 1670-5. [http://dx.doi.org/10.1001/archinte.167.15.1670]

[43] Voiculescu VM, Lupu M, Papagheorghe L, Giurcaneanu C, Micu E. Psoriasis and metabolic syndrome-scientific evidence and therapeutic implications. J Med Life 2014; 7(4): 468-71. [PMID: 25713604]

[44] Armstrong AW, Harskamp CT, Armstrong EJ. Psoriasis and metabolic syndrome: A systematic review and meta-analysis of observational studies. J Am Acad Dermatol 2013; 68(4): 654-62. [http://dx.doi.org/10.1016/j.jaad.2012.08.015] [PMID: 23360868]

[45] Langan SM, Seminara NM, Shin DB, et al. Prevalence of metabolic syndrome in patients with psoriasis: A population-based study in the United Kingdom. J Invest Dermatol 2012; 132(3 Pt 1): 556-62. [http://dx.doi.org/10.1038/jid.2011.365] [PMID: 22113483]

[46] Ogdie A, Yu Y, Haynes K, et al. Risk of major cardiovascular events in patients with psoriatic arthritis, psoriasis and rheumatoid arthritis: A population-based cohort study. Ann Rheum Dis 2015; 74(1): 326-32.

[http://dx.doi.org/10.1136/annrheumdis-2014-205675]

[47] Lin HW, Wang KH, Lin HC, Lin HC. Increased risk of acute myocardial infarction in patients with psoriasis: A 5-year population-based study in Taiwan. J Am Acad Dermatol 2011; 64(3): 495-501. [http://dx.doi.org/10.1016/j.jaad.2010.01.050] [PMID: 21216492]

[48] Wu JJ, Choi YM, Bebchuk JD. Risk of myocardial infarction in psoriasis patients: A retrospective cohort study. J Dermatolog Treat 2015; 26(3): 230-4. [http://dx.doi.org/10.3109/09546634.2014.952609] [PMID: 25102892]

[49] Lai YC, Yew YW. Psoriasis as an independent risk factor for cardiovascular disease: An epidemiologic analysis using a national database. J Cutan Med Surg 2016; 20(4): 327-33.

[http://dx.doi.org/10.1177/1203475415602842] [PMID: 26316538]

[50] Li WQ, Han JL, Manson JE, et al. Psoriasis and risk of nonfatal cardiovascular disease in U.S. women: A cohort study. Br J Dermatol 2012; 166(4): 811-8. [http://dx.doi.org/10.1111/j.1365-2133.2011.10774.x] [PMID: 22175820]

[51] Levesque A, Lachaine J, Bissonnette R. Risk of myocardial infarction in canadian patients with psoriasis: A retrospective cohort study. J Cutan Med Surg 2013; 17(6): 398-403. [PMID: 24138976]

[52] Abuabara K, Azfar RS, Shin DB, Neimann AL, Troxel AB, Gelfand JM. Cause-specific mortality in patients with severe psoriasis: A population-based cohort study in the U.K. Br J Dermatol 2010; 163(3): 586-92. [http://dx.doi.org/10.1111/j.1365-2133.2010.09941.x] [PMID: 20633008]

[53] Naik HB, Natarajan B, Stansky E, et al. Severity of psoriasis associates with aortic vascular inflammation detected by FDG PET/CT and neutrophil activation in a prospective observational study. Arterioscler Thromb Vasc Biol 2015; 35(12): 2667-76. [http://dx.doi.org/10.1161/ATVBAHA.115.306460] [PMID: 26449753]

[54] Bańska-Kisiel K, Haberka M, Bergler-Czop B, Brzezińska-Wcisło L, Okopień B, Gąsior Z. Carotid intima-media thickness in patients with mild or moderate psoriasis. Postepy Dermatol Alergol 2016; 33(4): 286-9.

[http://dx.doi.org/10.5114/ada.2016.61605] [PMID: 27605900]

[55] Fantuzzi G. Adipose tissue, adipokines, and inflammation. J Allergy Clin Immunol 2005; 115(5): 911-9. [http://dx.doi.org/10.1016/j.jaci.2005.02.023] [PMID: 15867843]

[56] Wellen KE, Hotamisligil GS. Inflammation, stress, and diabetes. J Clin Invest 2005; 115(5): 1111-9. [http://dx.doi.org/10.1172/JCI25102] [PMID: 15864338]

[57] Boehncke S, Thaci D, Beschmann H, et al. Psoriasis patients show signs of insulin resistance. Br J Dermatol 2007; $157(6): 1249-51$. [http://dx.doi.org/10.1111/j.1365-2133.2007.08190.x] [PMID: 17916217]

[58] Al-Mutairi N, Al-Farag S, Al-Mutairi A, Al-Shiltawy M. Comorbidities associated with psoriasis: An experience from the Middle East. J Dermatol 2010; 37(2): 146-55. [http://dx.doi.org/10.1111/j.1346-8138.2009.00777.x] [PMID: 20175849]

[59] Azfar RS, Seminara NM, Shin DB, Troxel AB, Margolis DJ, Gelfand JM. Increased risk of diabetes mellitus and likelihood of receiving diabetes mellitus treatment in patients with psoriasis. Arch Dermatol 2012; 148(9): 995-1000. [http://dx.doi.org/10.1001/archdermatol.2012.1401] [PMID: 22710320] 
[60] Henseler T, Christophers E. Disease concomitance in psoriasis. J Am Acad Dermatol 1995; 32(6): $982-6$. [http://dx.doi.org/10.1016/0190-9622(95)91336-X] [PMID: 7751469]

[61] Cohen AD, Weitzman D, Dreiher J. Psoriasis and hypertension: A case-control study. Acta Derm Venereol 2010; 90(1): $23-6$. [http://dx.doi.org/10.2340/00015555-0741] [PMID: 20107721]

[62] Ena P, Madeddu P, Rappelli A, Cerimele D. Serum angiotensin-converting enzyme activity in psoriasis. Dermatologica 1987; 174(3): 110-3. [http://dx.doi.org/10.1159/000248999] [PMID: 3030832]

[63] Ryder KW, Epinette WW, Jay SJ, Ransburg RC, Glick MR. Serum angiotensin converting enzyme activity in patients with psoriasis. Clin Chim Acta $1985 ; 153(2): 143-6$ [http://dx.doi.org/10.1016/0009-8981(85)90165-2] [PMID: 2998646]

[64] Cornier MA, Dabelea D, Hernandez TL, et al. The metabolic syndrome. Endocr Rev 2008; $29(7): 777-822$. [http://dx.doi.org/10.1210/er.2008-0024] [PMID: 18971485]

[65] Sunitha S, Rajappa M, Thappa DM, et al. Comprehensive lipid tetrad index, atherogenic index and lipid peroxidation: Surrogate markers for increased cardiovascular risk in psoriasis. Indian J Dermatol Venereol Leprol 2015; 81(5): 464-71. [http://dx.doi.org/10.4103/0378-6323.163734] [PMID: 26323680]

[66] Miller IM, Skaaby T, Ellervik C, Jemec GB. Quantifying cardiovascular disease risk factors in patients with psoriasis: A meta-analysis. Br J Dermatol 2013; 169(6): 1180-7. [http://dx.doi.org/10.1111/bjd.12490] [PMID: 23815240]

[67] Akhyani M, Ehsani AH, Robati RM, Robati AM. The lipid profile in psoriasis: A controlled study. J Eur Acad Dermatol Venereol 2007; 21(10): 1330-2. [http://dx.doi.org/10.1111/j.1468-3083.2007.02260.x] [PMID: 17958837]

[68] Reynoso-von Drateln C, Martinez-Abundis E, Balcazar-Munoz B, et al. Lipid profile, insulin secretion, and insulin sensitivity in psoriasis. J Am Acad 2003; 48(6): 882-5

[69] Endo Y, Yokote K, Nakayama T. The obesity-related pathology and Th17 cells. Cell Mol Life Sci 2017; 74(7): 1231-45. [http://dx.doi.org/10.1007/s00018-016-2399-3] [PMID: 27757507]

[70] Myśliwiec H, Baran A, Harasim-Symbor E, et al. Serum fatty acid profile in psoriasis and its comorbidity. Arch Dermatol Res 2017; 309(5): 371-80. [http://dx.doi.org/10.1007/s00403-017-1748-x] [PMID: 28585093]

[71] Baran A, Świderska M, Bacharewicz-Szczerbicka J, Myśliwiec H, Flisiak I. Serum fatty acid-binding protein 4 is increased in patients with psoriasis. Lipids 2017; 52(1): 51-60. [http://dx.doi.org/10.1007/s11745-016-4211-4] [PMID: 27864793]

[72] Kralisch S, Fasshauer M. Adipocyte fatty acid binding protein: A novel adipokine involved in the pathogenesis of metabolic and vascular disease? Diabetologia 2013; 56(1): 10-21. [http://dx.doi.org/10.1007/s00125-012-2737-4] [PMID: 23052058]

[73] Xu A, Tso AW, Cheung BM, et al. Circulating adipocyte-fatty acid binding protein levels predict the development of the metabolic syndrome: A 5-year prospective study. Circulation 2007; 115(12): 1537-43. [http://dx.doi.org/10.1161/CIRCULATIONAHA.106.647503] [PMID: 17389279]

[74] Furuhashi M, Saitoh S, Shimamoto K, Miura T. Fatty acid-binding protein 4 (FABP4): Pathophysiological insights and potent clinical biomarker of metabolic and cardiovascular diseases. Clin Med Insights Cardiol 2015; 8(Suppl. 3): 23-33. [PMID: 25674026]

[75] Correia B, Torres T. Obesity: A key component of psoriasis. Acta Biomed 2015; 86(2): 121-9. [PMID: 26422425]

[76] Duarte GV, Silva LP. Correlation between psoriasis' severity and waist-to-height ratio. An Bras Dermatol 2014; 89(5): 846-7. [http://dx.doi.org/10.1590/abd1806-4841.20142854] [PMID: 25184937]

[77] Chen YJ, Wu CY, Shen JL, et al. Psoriasis independently associated with hyperleptinemia contributing to metabolic syndrome. Arch Dermatol 2008; 144(12): 1571-5. [http://dx.doi.org/10.1001/archderm.144.12.1571] [PMID: 19075139]

[78] Zhu KJ, Zhang C, Li M, Zhu CY, Shi G, Fan YM. Leptin levels in patients with psoriasis: A meta-analysis. Clin Exp Dermatol 2013; 38(5): 478-83. [http://dx.doi.org/10.1111/ced.12171] [PMID: 23777488]

[79] Hamminga EA, van der Lely AJ, Neumann HA, Thio HB. Chronic inflammation in psoriasis and obesity: Implications for therapy. Med Hypotheses 2006; 67(4): 768-73 [http://dx.doi.org/10.1016/j.mehy.2005.11.050] [PMID: 16781085]

[80] Stallmeyer B, Kämpfer H, Podda M, Kaufmann R, Pfeilschifter J, Frank S. A novel keratinocyte mitogen: Regulation of leptin and its functional receptor in skin repair. J Invest Dermatol 2001; 117(1): 98-105. [http://dx.doi.org/10.1046/j.0022-202x.2001.01387.x] [PMID: 11442755]

[81] Kadry D, Hegazy RA, Rashed L. Osteopontin and adiponectin: How far are they related in the complexity of psoriasis? Arch Dermatol Res 
2013; 305(10): 939-44.

[http://dx.doi.org/10.1007/s00403-013-1392-z] [PMID: 23884541]

[82] Griffiths CE, Barker JN. Pathogenesis and clinical features of psoriasis. Lancet 2007; 370(9583): $263-71$. [http://dx.doi.org/10.1016/S0140-6736(07)61128-3] [PMID: 17658397]

[83] Baran A, Flisiak I, Jaroszewicz J, Świderska M. Effect of psoriasis activity on serum adiponectin and leptin levels. Postepy Dermatol Alergol 2015; 32(2): 101-6.

[http://dx.doi.org/10.5114/pdia.2014.40960] [PMID: 26015779]

(C) 2018 Buquicchio et al.

This is an open access article distributed under the terms of the Creative Commons Attribution 4.0 International Public License (CC-BY 4.0), a copy of which is available at: (https://creativecommons.org/licenses/by/4.0/legalcode). This license permits unrestricted use, distribution, and reproduction in any medium, provided the original author and source are credited. 